\title{
Ruth Landes and the remaking of the anthropological canon
}

José Hildo de Oliveira Filho'

' Universidade Carolina de Praga, República Tcheca

\begin{abstract}
This article analyses Ruth Landes' contributions to social anthropology based on a series of feminist, queer and postcolonial insights. Landes' academic trajectory and her biography are used to understand her unique form of writing ethnographies. I try to show that "The City of Women" (originally published in 1947) does not follow classic anthropological tropes present in ethnographies in the 1930s and 1940s. Her rejection of canonical ways of writing is not only a stylistic choice but a result of Landes' social trajectory. For this reason, "The City of Women" is an essential work in the effort to understand the ever-present challenges posed by writing ethnographic texts.
\end{abstract}

Key words: Women in Anthropology; Sexuality; Classic Ethnographies; Ruth Landes.

\section{Ruth Landes e a reconstrução do cânone antropológico}

\section{Resumo}

O presente artigo utiliza uma série de insights feministas, queer e pós-coloniais para analisar as contribuições de Ruth Landes à antropologia social. Por todo o texto, a trajetória acadêmica e a biografia de Landes são amplamente utilizadas para que se entenda o seu jeito único de escrever etnografias. Como tento mostrar, Cidade das Mulheres (originalmente publicado em 1947) não segue tropos antropológicos clássicos presentes nas etnografias dos anos 1930 e 1940. E a rejeição de modos canônicos de escrita etnográfica não é somente uma escolha estética, mas o resultado da trajetória social de Ruth Landes. Neste sentido, Cidade das Mulheres é um importante trabalho para entendermos os desafios presentes na escrita de textos etnográficos.

Palavras-chave: Mulheres na Antropologia; Sexualidade; Etnografias Clássicas; Ruth Landes. 


\title{
Ruth Landes and the remaking of the anthropological canon
}

\author{
José Hildo de Oliveira Filho
}

\begin{abstract}
Negro women were everywhere, in colorful skirts and turbans and white blouses reflecting the sun. Usually they were older women, powerful in appearance and self-confident, and keenly interested in the work at hand. They managed the butcher shops, the vegetable stalls, the candy and flower bars, and the stands selling spices, soaps, beads, and other specialties imported from the west coast of Africa. The trade with Africa had been going on since the loading of the first slave ship.
\end{abstract}

Ruth Landes, The City of Women, 1947.

\section{Ruth Landes, ethnography and anthropology}

In a recent debate in Hau:Journal of Ethnographic Theory (2017), Signe Howell, Tim Ingold, Alpa Shah, Giovanni da Col, Daniel Miller, Rita Astuti, Thorgeir Kolshus and Maurice Bloch shared their visions on the definitions and relations between participant observation, ethnography, and anthropology, and how anthropologists can effect changes in the contemporary world. This debate was sparked by Tim Ingold's (2014, p. 381) provocation that he was: "Sick and tired of equivocation, of scholarly obscurantism, and of the conceit that turns the project of anthropology into the study of its own ways of working".

Ingold has previously raised the same arguments to express his concerns (2011 [2007]) that ethnography had been turned loose within other disciplines. This use of ethnography by sociologists and political scientists, he affirmed, threaten the long-term commitment, and the generous dialogues anthropologists engage with others.

According to Ingold (2014), if we persist in using the Geertzian understanding that (1973, p. 5) "in anthropology, or anyway in social anthropology, what the practitioners do is ethnography", we risk not being able to clarify what are the specific features of anthropological fieldwork to other disciplinary traditions that are appropriating ethnography. Thus, Ingold suggests we drop "ethnography" and state that anthropologists do "participant observation". A method that is based on an exploration of the different conditions and possibilities of being human.

Participant observation, Ingold suggests, involves a practice of education of the self. By paying attention to others and what they do, anthropologists are able to construct an intersubjective form of knowledge that is not confined to what is presented in school systems. This education is based on the original sense of the Latin world educere to mean that apprentices are educated when they are out in the world.

Thus, more than a critique of the ways sociologists and political scientists use ethnography, Ingold seems to have an additional target: neoliberalism at universities. Without a proper definition of participant observation, ethnography and anthropology, he affirms that anthropology may fall into "irrelevance". The irony seems impressive. At the moment in which ethnography is "expanding", the ethical commitments 
of anthropology seem to be lost. Other disciplines are in principle embracing a more technocratic view of ethnography in which ethnographic research is understood to mean "qualitative"" research.

Anthropology, according to Ingold, could be defined as a discipline that is generous, opened-ended and comparative. Anthropology's generosity is predicated on its ability to listen to others. While he affirms that its open-endedness and comparative nature are related to the idea that anthropology seeks no final answer to its questions, and knows that there are various ways of organising both societies and symbolic worlds. These characteristics should be analytically separated from specific ethnographies, because Ingold maintains that anthropology must find a way to participate in contemporary political debates, in which anthropologists should claim a perspective that problematizes the conditions of human life on earth. In this sense, for Ingold, anthropologists have one goal: to educate others to respect and appreciate the world's diversity.

Here things get a bit more complicated. If all the participants in the debate seem to be tired of "scholarly obscurantism", they have few suggestions about how to educate others beyond a Western public within neoliberal universities. In this sense, Daniel Miller's and Thorgeir Kolshus's contributions seem to be the only ones genuinely concerned with communicating beyond the confines of the university walls.

Miller (2017, p. 29) takes an entirely different route than Ingold. According to Miller, the goal of anthropology is not to question and compare the conditions of life on earth, but to only "do ethnography". This view entails that anthropologists should understand that no matter how many ethnographies they produce; the world's cultural diversity will be much wider than the discipline's scope. This "humility" is Miller's (2017, p. 29) way of objecting to Ingold's definition of anthropology. In response to Ingold's attacks on neoliberalism, Miller states:

We often criticize something called neoliberalism, which has many potential definitions. One of these would be a perspective in which the unit of value has become the isolated individual instead of some wider social or collective value. When I started anthropology, our units of value tended to be The Nuer, The Trobriand Islanders, or the Kwakiutl, but today all the discussion around me seems to be asking whether someone is aligned with Bruno Latour or Nancy Scheper-Hughes or Arjun Appadurai (or is he now too "last year"?). A world of citations and brand-like individual names.

While other participants in the debates are more conciliatory, such as Rita Astuti (2017) and Signe Howell (2017), I will try to offer support to Miller's position. Anthropologists should not imagine that we are immune to criticism. Another aspect raised by Miller is his team of researchers' efforts to present their ethnographies to secondary students in the British "A" levels. Since there are increasingly fewer anthropology students in the "A" levels, Miller and his team aligned with sociology teachers.

Interestingly enough, if the task of anthropologists, according to Ingold, is to educate, there are very few practical proposals on how to effectively bring anthropology to public school systems. Miller and Kolshus are the only ones who seem to be interested in turning ethnographic stories into pedagogical projects at the public school level. To avoid our decline into "irrelevance", Miller (2017, p. 30) affirms we should ask ourselves:

\footnotetext{
1 One of the main features of the Hau debates seems to be the fact that anthropologists seem inclined to ignore the history of participant observation and ethnography as both sociological and anthropological methodologies. For example, Becker (1999) analyses how the "Chicago school" helped to create both urban sociology and anthropology based on a series of methodological innovations. Other social sciences projects such as the CCCS Birmingham (Hall and Jefferson, 2002 [1975]) or the French sociologists working with Pierre Bourdieu (2000) are simply ignored. These historical "lapses" allow ignoring a muchblurred history of ethnography, beyond the confines of anthropology. In fact, in Shah's (2017) contribution, we see an oscillation between a "tribal language" (such as one that affirms that anthropologists are "the inventors of ethnography") and possible uses of ethnography to build alliances across disciplines. Shah is the only one who remembers Paul Willis or James Scott, for instance.
} 
How many Brexits must we live through, where we know that a prime cause of the result was that so far from people gaining a wide appreciation and empathy for other peoples, we see instead a xenophobic resistance to even encountering people from elsewhere? How many Trumps must we live through, where we know this was again a primary cause of his success, before we stand up and state clearly that anthropology has greater responsibilities to the world than just its own intellectual conceit?

Miller's accusation that the field has an obsession with "its own intellectual conceit", turns Tim Ingold into the "inward-looking" anthropologist that Ingold himself rejects. However, I can't help but notice another irony in this debate. All the participants work in the Global North. And there is no attention to the possible ways anthropologists in the Global South might be facing the challenges of education and political intervention in public school systems. ${ }^{2}$ It seems that the generosity of anthropologists has some limits. Simply ignoring other ways to do fieldwork (see Peirano, 1998), and insisting that other anthropologists "get the words right ${ }^{3}$ " reinstates the Eurocentrism which we sought to avoid long ago.

No one will deny that fieldwork has been the hallmark of social anthropology. However, historically, only some experiences counted as "actual fieldwork". The disputes over what is good fieldwork and ethnographic writing have shown the different ways in which anthropologists engage with the increasingly diverse contexts opened for scrutiny by social scientists.

These disputes are seen in criticisms by postcolonial thinkers ${ }^{4}$ (Said, 1994) of classical fieldwork methods. The power relations involved in doing fieldwork and writing ethnographies are also under careful analysis (Geertz, 1968; Ginzburg, 1989). And even the possibilities for ethnographic textual expression are challenged by contemporary globalization, with its massive immigration, global network connections and communication mediums (Abu-Lughod, 2006 [1991] Hannerz, 2003). Feminist and queer critiques of knowledge building processes (Haraway, 1988; Butler, 1999 [1990]) are also powerful tools for analysing the ethical responsibility of anthropologists in their discursive practice.

One way to apply interdisciplinary, critical postcolonial and feminist approaches to anthropology is to analyse experiences not considered to be "proper fieldwork" and that did not fit the canon of ethnographic writing (Clifford, 1980). This is the goal of my work. I will analyse the ethnographic experience and writings of Ruth Landes. My focus in this article will be primarily on how Landes conceptualized women's agency in her fieldwork in Salvador, Brazil, on Afro-Brazilian religions, in 1938 and 1939 (Landes, 1994 [1947]). However, other aspects are also important: Ruth Landes is seen today as a transitional figure (Cole, 2003), since her ethnographic writing presaged our concerns about power, agency and our own positionality.

In this sense, to justify the focus on her work, I can recall that academics are still debating how to decolonize our theories and practices (Strathern, 1987; Mohanty, 2003). And because Landes was an academic outsider, her example may help us understand why anthropologists ignored the textual expressions she explored in the 1930s and 40s. Another form of justification is directly related to the Hau debate. I strongly believe that anthropologists should intervene in public education systems. In doing so, we cannot forget the history of anthropological experiences. Otherwise, in trying to educate, we may produce even more equivocation.

\footnotetext{
2 No scholar from the Global South was either invited to the SOAS debate "Two or three things I love or hate about ethnography" in 2016 or asked to contribute to the debates published at $\mathrm{Hau}$ (Da Col, 2017).

3 Miller also states his claim against Ingold's use of ethnography, fieldwork, and participant observation. He says (2017, p. 27): “The problem is that for generations, anthropologists have been using terms such as fieldwork, ethnography, and participant observation as more or less synonymous and in effect as the terms for our method. I suggest therefore that it would be better to accept the colloquial meaning and definition of ethnography and work from there. Unlike Ingold, I will use the term ethnography in the way I think most people routinely use it."

4 Social anthropology is often accused of being a form of symbolic colonialism. This accusation neglects a Foucauldian construction: that scientific discourses not only create the realities they claim merely to be describing, but they can also be used by the subjects they address to build resistance (Foucault, 1998 [1978]). An analysis of how tribal societies used the anthropological concept of "culture" to claim their distinctiveness can be found in the work of Marshall Sahlins (1993).
} 


\section{Ruth Landes' academic trajectory}

Through field work at the pleasure of the host culture one learns one's place there and that it is the only vantage point for penetrating the culture. Mistakes and mishaps in the field are great lamps of illumination; if one survives.

Ruth Landes, A Woman Anthropologist in Brazil, 1970.

Ruth Landes was already an experienced researcher when she arrived in Brazil. She had done fieldwork among tribal societies, such as the Ojibwa and the Potawatomi in Canada and the United States, respectively. These previous fieldwork experiences would mark her style of framing women's agency in her writing (Anderson, 2012; 2013; Cole, 2002; 2003).

Among the Ojibwa, Landes worked closely with Maggie Wilson. Wilson was Landes' "key informant." She collected over 100 women's stories and shared them with Landes. "Informants" in the history of anthropology are often seen as non-complex figures. According to recent analysis, however, the opposite is the case. Their capacity to mediate contacts and be the main translators gives them a special role in understanding the limitations and possibilities of fieldwork (Clifford, 1983). This uniqueness and complexity is illustrated by the case of Maggie Wilson. The stories Wilson and Landes collected portrayed women fighting against the commonly accepted rules among the Ojibwa, instigating Landes' decisive interest in power and agency.

Crossing gendered boundaries concerning labor (such as for hunting) and renegotiating marriage rules were vital marks of the development of women's autonomy among the Ojibwa. Landes' writing examined not only the regularities of Ojibwa society, but also its flexibility and conflicts. ${ }^{5}$ In this way, she escaped many essentializing features that were common in ethnographies in the 193os. As Abu-Lughod (2006 [1991]) wrote:

Anthropologists commonly generalize about communities by saying that they are characterized by certain institutions, rules, ways of doing things like "The Bongo-Bongo are polygynous". Yet one could refuse to generalize in this way, instead asking how a particular set of individuals - for instance, a man and his three wives in a Bedouin community in Egypt whom I have known for a decade - live the "institution" that we call polygyny (Abu-Lughod, 2006 [1991], 162).

We can see that her fieldwork experience among the Ojibwa led Landes to question the capacity of anthropological fieldwork to generalize, since she focused on lived experiences of social change ${ }^{6}$ (see also Corrêa, 2002). The lived experiences, present in the exchanges during her fieldwork, played a deep role in Landes' view of practice, power and agency. ${ }^{7}$

Among the Potawatomi, Landes saw gender roles in narratives about Berdaches, "trans" women who were becoming rarer, according to the Potawatomi. This context of more rigid gender roles didn't stop Landes from understanding the dynamics of gender transitioning, forms of addressing transgender women and large social changes among the Potawatomi (Cole, 2002). ${ }^{8}$

\footnotetext{
5 For an interpretation of Landes' ethnography on the Ojibwa see Sally Cole's article "Women's Stories and Boasian texts: The Ojibwa ethnography of Ruth Landes and Maggie Wilson (1995a).

6 In the preface of the Brazilian edition of "The City of Women”, Mariza Corrêa (2002) draws on an intense dialogue with Sally Cole to construct an analysis of Landes' ethnographic experiences in Salvador based on her previous engagements with the Ojibwa and the Potawatomi.

7 Abu-Lughod (2006 [1991]) also notes that there is a shift from "culture" as a generalizing concept to "discourse" and "practice" in contemporary fieldwork practice, both of which are more locally grounded and flexible. The basis for the use of discourse and practice (at least in anthropology) is found in the works of Michel Foucault (1998 [1978]) and Pierre Bourdieu (2000 [1997]).

8 Readers of Landes' portrait of the Potawatomi find a personal account dedicated mostly to Joe Masquat and J.S (John Smocks), the two shamans who guided Landes through their symbolic worlds (see Landes, 1970).
} 
Landes' writing style, and her enduring interest in gender-related themes, was not only constructed through her fieldwork experiences. It was also the fruit of her personal life. Born into a Ukrainian-Russian immigrant family in 1908 in New York, Landes completed a master's degree in social work in 1929 and married Victor Landes in the same year. The marriage soon ended because of Landes' interest in pursuing her Ph.D. studies. To revolt against the destiny of a housewife, in 1931 she officially began her studies in the department of anthropology, under Ruth Benedict's supervision, at Columbia University (Cole, 1995a).

Landes' arrival in Brazil was thus conditioned by the historical context of the 1930s. The institutionalization of the social sciences was incipient, with the establishment of the University of São Paulo and stronger partnerships between North American universities and the National Museum in Rio de Janeiro (Massi, 1991; Corrêa, 2000; Salzano, 2009). Many European and North American social scientists would participate in this process. Columbia University also played an important role by hosting Brazilian scholars (such as Gilberto Freyre and Eduardo Galvão) and sending many anthropologists to do fieldwork in Brazil (Charles Wagley, Buell Quain and others) through a partnership with the National Museum in Rio de Janeiro. Landes was part of a bigger project, which focused mainly on a comparison between race relations in Brazil and the USA. To prepare her for fieldwork, she was advised by Robert E. Park to teach at Fisk University in Tennessee, a black university.

The goal of this preparatory phase, according to Park, was "to get used to Negroes" (Landes, 1994 [1947]: p. 2). In Landes' "The City of Women," she used this teaching experience to analyse herself and her ethical and political positions on racial discrimination, since she saw herself as a "northerner".9

In the next section, I will examine how Landes' ethnographic work on Afro-Brazilian religions was understood at the time and the consequences she faced for the way she wrote her ethnography.

\section{3. "The City of Women" and its reception}

The woman anthropologist is a professional worker, which means that she is measured by the standards attached to men since the work is in a public sphere - the sphere controlled by men in our world. But her training as "a man" did not start until her anthropology did.

Ruth Landes, “A Woman Anthropologist in Brazil”, 1970.

In a review of "The City of Women," published in the American Anthropologist journal, Herman Melville J. Herskovits (1948) called attention to the popular style Landes used to write her ethnography. This form, he claimed, was a way to attract the general public, not only professional anthropologists. However, he based other critiques of Landes' writing on methodological grounds, alleging that she wasn't sufficiently trained to undertake fieldwork in a Brazilian city. At the beginning of her ethnography, Landes wrote:

We knew extremely little about Brazil at that time, and the general feeling among my colleagues was that I was being sent to the margins of the tableland of the world, where only luck could keep me from falling off (Landes, 1994 [1947], p. 1).

\footnotetext{
9 This preparatory phase was attacked by scholars such as Herskovits (1948). Scholars concerned with African-American studies would see this teaching period at Fisk University as insufficient, arguing that Landes was under prepared when she did her fieldwork in Brazil.
} 
Landes' fear before beginning her fieldwork in Brazil, which she dared to confess in her final writing, was based, according to Herskovits, on the lack of a good preparatory phase, and compounded by Landes' lack of knowledge about Africa. ${ }^{10}$

Supported by the paradigm of acculturation, Herskovits believed that the interpretation of religious' traditions among blacks in the Americas had to be constructed by making contrasts with the "original" African matrix. ${ }^{11}$ Her experiences during her preparatory phase teaching at Fisk University led Landes to find this approach quite problematic. For her, the interpretation of blacks as "tribesmen" inside modern societies was a form of racial discrimination, characteristic of American society:

But in the United States, Negroes were regarded, even by liberals and scholars, as a sort of tribe - not the same as white men, but not the same as modern men (Landes, 1994 [1947]: p. 3).

The paradigm of acculturation, in vogue in U.S. anthropology in the early 2oth century, believed that the advance of the West would do away with cultural diversity on the planet. As the West advanced, it would be possible to measure the distance that separated tribal societies from Western ones (Pacheco de Oliveira, 1988). This distance could be measured by anthropologists, as a way of observing social changes. Thus, Landes' ethnographic practice, in a modern city such as Salvador, could serve as a response to the "acculturation paradigm" - which became highly criticized after World War II. ${ }^{12}$

Ultimately, Landes was operating with another notion of social change: the problem for her was to see the Afro-Brazilian religions on their own terms. The questions were not targeted to understand how close or distant Afro-Brazilian religions are from the "original," but to comprehend how memory and history were and are recreated and reinterpreted by these religious communities in the Americas (Cole, 1995b). ${ }^{13}$

The debate about ethics and methodology between Landes and Herskovits, reveals the challenge that "travelling cultures" (Clifford, 1997) posed to anthropology. African-American cultural expressions compelled social anthropology into interdisciplinary inquiries. Herskovits himself would admit that in researching "accultured" societies, anthropologists had to do research in historical archives, as well as fieldwork.

The terms of debate between Landes and Herskovits were not new. Discussions about the problems involved in understanding the connections between Africa and Brazil are present in the history of AfroBrazilian religious studies in general. There are many proposals for how to best address this issue. However, as Anne McClintock's genealogy of the concept of "fetishism" notes, the invention of the "primitive" is a hallmark of modernity and its disciplined bodies (McClintock, 1995, pp. 181-203). What anthropologists such as Herskovits understood when they identified the "African cultural matrix" as "original" and the African-related religious institutions in the Americas as "survivals", was a trope borrowed from colonial rhetoric. As a "black characteristic" that could not be erased in modern times, the "fetishism" (also present in Afro-Brazilian religions) was a form of drawing boundaries and hierarchies, based on racial and presumably psychological differences.

\footnotetext{
10 Landes indeed worked with a largely ahistorical concept of culture, in which conditions observed by ethnographic methods in the present were often generalized. However, we can see in her trajectory that her way of conducting ethnographies also caused her trouble. Her work among the Ojibwa was described as "unscientific" because it was "biased" towards a women's point of view (see Cole, 1995a).

11 For a brief definition of Afro-Brazilian Candomblé, see Allen (2008).

12 Other studies have found that Landes' "ethical deed" was born out of her romance and intellectual partnership with Edison Carneiro (see Anderson, 2012, 2013).

13 Arthur Ramos (2010 [1942]) research deeply questioned Landes' ethnographic practice. He boldly stated that "her knowledge of the bibliography on Blacks not only in Brazil but also in North America was virtually zero”. Ramos's article trigged a response from Carneiro (2010 [1964]) in defense of Landes' ethnographic methods.
} 
In this regard, Ruth Landes made interesting contributions to the ethnographic tradition of AfroBrazilian religious studies (see also Landes 1953, 2010). One of them was a decisive non-essentialist and anti-primordialist approach. Landes did not see the Afro-Brazilian religions as museum pieces, destined to perish. That is why so many conflicts between terreiros (ritual sites) were very well documented. AfroBrazilian religions were portrayed through Landes' personal encounters with priests and priestesses and the dialogical exchanges with them were exposed in such a way that the subjects studied were placed in a context of contemporary history. This made her claim not to see blacks as "child-like or tribal-minded people" an important ethical position. We can see this characteristic way of writing in her encounter with Dona Menininha, one of the most respected Candomblé priestess in Bahia at the time:

"There is a great deal I need to learn, my mother," I said, sighing to think of the tremendous imponderables of life in Bahia. "You see, we have no candomblés in North America."

"No?" She was surprised and disapproving. "Don't your people believe in God?"

"Oh, yes, but we show it in other ways. Still, we have much to learn."

"You want to learn from us?" Her tone was cold.

"Yes," I ventured.

"But there are secrets here you may not learn."

"It is not the secrets I want, my mother. I want only to understand your beliefs. I want to learn more about God, and about men because they are my brothers" (Landes, 1994 [1947]: 82-83).

Landes, however, did not construct her ethnography free from any claim of an authoritative voice. Yet, she enounces her authority with an innovative way of situating herself as an anthropologist - by constructing a contrast between herself and the American community she met in Salvador.

If at first sight it seems that Landes appeals to a long-term tradition based on contrasting Brazil and the United States, at a closer look we must acknowledge the ambiguities that her form of comparison brings. She presented a series of stereotypes that American expats in Salvador constructed about Afro-Brazilian religions, to contrast their common-sense beliefs about blacks and Landes' ethnographic experience.

By doing this, Landes showed how the borders of Afro-Brazilian religions are constantly created and maintained. The allusive reference to local press discourses and their prejudices is another part of an attentive ethnographic contribution. Landes also situates herself as a white American anthropologist in these passages. Her walks around working-class neighbourhoods in Salvador are only made possible because she is accompanied first by Jorge, a Brazilian clerk at the American consulate, and then by Edison Carneiro, a Brazilian intellectual who accompanied Landes to Candomblé religious sites. ${ }^{14}$ In her comments on these walks, we are told that a single and unaccompanied woman had very little possibility to learn about the living conditions of "poor and ignorant" blacks (1994 [1947], p. 137) in Salvador. Simply by walking around poor neighbourhoods and Candomble terreiros, Landes attracted the surveillance of the Salvador police towards her fieldwork (see Landes, 1986 [1970]).

One consequence of the fact that Landes saw both the American expat community and the AfroBrazilian religion as part of a continuum is that we can now read her as a pioneer in unmasking whiteness.

14 Landes (1986 [1970], p. 128) would later express her collaboration with Edison Carneiro as follows: "Never in the history of field work, I am confident, has anyone been more fortunate than I in the association with Edison. Apart from Edison's repute as a scholar and writer, and apart from his talents and character, the fact was that I could not have stirred a step in Bahia without his, a man's 'protection"'. Carneiro was in fact much more than a "collaborator" in Landes' fieldwork. They were romantically involved. Cole (2003), in analyzing their correspondence, saw the exchange of affectionate letters between Edison and Ruth, and the plans they made, after Landes left Brazil. They tried to live together in Britain or the United States. But with the outbreak of World War II, and the economic hardships both Edison Carneiro and Ruth Landes faced, the possible marriage did not happen. 
As Frankenberg (1993) showed, whiteness as a standpoint carries the implicit privilege of belonging to an "unmarked" perspective. By taking long walks with Jorge, and connecting her experiences at Afro-Brazilian ritual sites with those with the American community, Landes makes the white American gaze visible. The American community's gaze often appealed to an essentialized racist rhetoric to maintain its boundaries from Salvador's "natives".

Furthermore, at the time, anthropologists tended to distance themselves from other nationals who had "untrained" contacts with the subjects they were studying.

Upon my arrival I met members of the small American colony that lived a fretful and bored existence on the handsomest and coolest heights of the city. They came from Texas, Oklahoma, Georgia, and had ironclad rules about relations with "natives," "niggers," "trash," and Jews. It was my first exposure to such a group, and it found me vulnerable. The couples were torn apart by infidelities and excess leisure and idleness. On the other hand, the group as a whole was bound with the intimacies resulting from the grief, the passions and fleeting affections, and the vital protection that each individual promised against total loneliness (Landes, 1994 [1947]: p. 11).

In this sense, "The City of Women" is at the same time a pioneering ethnography concerning positionality, dialogical writing (Marcus and Fischer, 1986), deconstructions of American racial stereotypes and a line of continuity in Landes' trajectory as an anthropologist. The characteristics of her writing are highly valued today as part of our writing methodologies (Livholts, 2012). However, as I discussed before, Landes herself had "gender troubles" in the 1930s: a Jewish, divorced, academic woman at the emergence of World War II, with scientific racism and anti-Semitic rhetoric at its highest level. ${ }^{15}$ Working with Afro-Brazilian religions, Landes constructed her ethnography through women's narratives in "The City of Women" to give us her most valuable contribution: the focus on gender, sexuality and agency in AfroBrazilian ritual sites. I will discuss these issues next.

\section{Matriarchy, sexuality and agency in "The City of Women"}

Field work serves an idiosyncrasy of perception that cannot separate the sensuousness of life from its abstractions, nor the researcher's personality from his experiences.

Ruth Landes, A Woman Anthropologist in Brazil, 1970

A reader familiar with Landes' work might object to the arguments presented so far in this paper, or some issues I have not addressed. For instance, I have not mentioned the "matriarchy debate". After all, Landes' interpretation of Candomblé as a "matriarchal" religion was the source of endless debates around her work (Ramos, 2010 [1942]; Carneiro 2010 [1964]; Fry, 1986, 2015; Matory, 2008; Anderson, 2012, 2013).

Nevertheless, I will concentrate on the methodological debate related to "the matriarch" discussions. The reason behind this is simple: Landes' conclusions cannot be discussed without mentioning the idiosyncratic ways she used ethnographic methods. Whether considering the positions of her detractors, such as Arthur Ramos, or supporters such as Edison Carneiro, who worked with Landes and defended her

\footnotetext{
15 One of Landes' enduring interests was how marriages could be constituted and dissolved. An interest that reflects her status as a divorced woman. We can see how this research interest is constructed throughout Landes' career. It is present not only in "The City of Women", but also in her previous works. Reflecting later on her experience among the Ojibwa, Landes wrote that she "wanted to know how different societies handled the same life situations of, for example, sexual desire and marriage, particular neuroses and psychoses, or formal recognition of success and failure in careers. [I] wanted to compare them to see where particular cultures set up different boundaries for acceptable conduct, and to see wherein all cultures behaved similarly, and to see how cultures changed" (Landes, 1965, apud Cole, 1995a).
} 
"ethnographic authority", these debates show that the path to a contemporary discussion about Landes' work resides in seriously considering the methodological debates she has helped to spark.

Instead of focusing on the "matriarch debates", I will concentrate on the ways in which "ethnographic authority" has changed. The increasing amount of studies on different aspects of Landes' ethnographies proves my point (Healey, 1996; Corrêa, 2000; 2002; Matory, 2005; 2008). My central argument in this article is that the change in "ethnographic authority" is forged through the entrance of women in academia and a series of questions presented by feminist, queer and postcolonial perspectives, as I mentioned in the introduction.

James Clifford ${ }^{16}$ (2003, p. 21) also recognized the profound transformation brought by feminist epistemologies when thinking about the writing of ethnographic texts:

Anthropology, which for so long spoke for difference, is caught up in, challenged by, the process by which the academy in the U.S. - and it is an uneven process - is becoming more diverse. What's at stake is the inclusion of people of diverse historical backgrounds, people who have been racialized differently and kept in subaltern social positions. Moreover, I would underline the major impact that women, and feminist perspectives, have had in my context. We sometimes forget how male-dominated the academy has been since the medieval university, how recent the emergence of a critical mass of women is. All of these changes, these multiplications of what my colleague Donna Haraway named "situated knowledges," undermine the ability of disciplines to naturalize their knowledges. Authority is fundamentally contested.

In this article, I will follow Clifford's discussion of Donna Haraway's (1988) notion of "situated knowledges", and try to apply it to Ruth Landes' life and the "authority" of her writing. Furthermore, I will avoid the "matriarch debates" because, as Sally Cole's works show (1995a; 1995b; 2002), Landes' ethnographic authority, throughout her life, was constantly undermined. Landes' work among the Ojibwa, for instance, was seen as a "partial" ethnography, excessively concerned about women's point of view (a claim that could hardly be made today, precisely because of the presence of women in academia).

Moreover, different from feminist discourses on matriarchy (such as those analysed by Butler in "Gender Trouble") which seek to forge women's solidarity by recreating a mythical past, Landes' matriarchy is an embedded and descriptive category used to account for the transmission of knowledge and power within Candomblé ritual sites.

However, Landes' description of a Candomblé matriarchy is still the "empirical error" that she is most remembered for. According to Matory (2005), Landes' claim that male priests were a minority in the 1930 s was highly controversial. If, indeed, some of the terreiros had a certain tradition of women leaders since the second half of the $19^{\text {th }}$ century (such as the Casa Branca), male priests were as numerous as female ones. To construct her argument, Landes did unite two separate and polemic issues: male priesthood and sexuality. ${ }^{17}$

In an article published in 1940 called "A cult matriarchate and male homosexuality," Ruth Landes analysed Caboclo ritual sites ${ }^{18}$. According to Landes, these terreiros were created by dissidents from the

16 Clifford and the Writing Culture (1986) group of academics were criticized for not including women anthropologists in their analysis of the ethnographic canon. Critics added that Clifford and his colleagues not only failed to include women anthropologists such as Margaret Mead, Ruth Benedict and others, but also failed to include women of color. Clifford justifies the absence of women in the introduction of the volume stating that women who were self-consciously feminists were not engaging in innovative ways of writing ethnographies. And women anthropologists who were innovative ethnographers were not feminists (see Behar, 1993; Behar and Gordon, 1995).

17 Matory's (2005) accusatory tone towards Landes' work is worth mentioning. He insists that Landes' "matriarchy” was a "partial” and "plausible” construction of tradition, but he links Landes' work with the ways journalists today mention Candomblés priestesses. The fact that more public funding goes to terreiros led by women, seems to Martory to be a conspiracy of the "imagined community of feminism" against male Candomblé priests (especially against gay priests).

18 The Caboclo religious institutions emerged in the 1930s in Rio de Janeiro and spread throughout Brazil. These religious institutions combined Amerindian beliefs with Catholic and African imagery. 
traditionalist Afro-Brazilian religions and these dissidents claimed that Caboclo priests had special contacts not only with African Gods, but also with indigenous people's deities.

However, according to Landes' interpretation, the Caboclo terreiros more easily accepted men becoming priests. These men were described by Landes as mostly gay men, who lived in poverty and were highly discriminated against. To become a priest in a Caboclo ritual site was a way of gaining access to religious secrets and be in a better position to negotiate relationships with other men and be able to wear women's clothes. Like the Potawatomi Berdaches and the Ojibwa women, Landes was facing another way in which crossing gender boundaries and negotiating social rules took shape.

Because Landes noted a trend toward a majority of woman among Candomblé priests, she would have to explain why there were also male priests in her "matriarchy". So Landes appealed to the "African tradition". She described the cross-gender practices in Candomble as part of that "tradition". Landes, however, constructed her own view of "tradition". A view that wanted to contrast American gender relations with those present in Afro-Brazilian religions.

In this vein, women's sexuality at other ritual sites was also described by Landes. To be part of a house and take part in the hierarchies of a terreiro meant more sexual freedom for women, since women were supposed to be involved in ritual obligations and didn't necessarily have to marry. Landes also described sexual and romantic encounters between women and men from different class backgrounds. These encounters were more or less made possible by the fact that some Afro-Brazilian ritual sites were attractive to the middle classes. However, the religious duties for the higher positions involved many disciplinary measures and sometimes sexual abstinence was one of them. As Landes wrote:

Among certain American Indian tribes, the Berdache or passive homosexual was protected, encouraged to adopt the social and sexual roles of women, sometimes to assume sacred responsibilities, and less often allowed to cultivate with social approval the lewd conduct we attribute to professional prostitutes (Landes, 1940, p. 386).

Therefore, even if Landes' interpretations of her data about the linkage between religion and sexuality among the North American Indian tribes and the Afro-Brazilian ritual sites is currently seen as objectionable, since she does not question the historical process that led to a "naturalization" of "sex" as a specific Western historical development (Foucault, 1998 [1978]), we should not see her contribution to these debates only as a historical documentation of social change in the late 1940s. In fact, when placed in the specific historic context, these debates mark Landes' distinctive contribution to social anthropology: the understanding of the relationship of gender and sexuality to social change.

Discussing her use of ethnography to capture changes and reflexively understand the limitations of generalizations and essentialisms, helps to see what Abu-Lughod (2006 [1991]) called "the women's tradition in social anthropology" (Behar and Gordon, 1995; Visweswaran, 1997). This women's tradition challenged many aspects of canonic ethnography by using various discursive strategies and claiming different ethical responsibilities for the knowledge they wrote about (Haraway, 1988; Gordon, 1993). Consequentially, Landes' ethnography is also an example of a "history of intersectionality," in which identities and positions, such as race, gender, class and sexuality, are not seen as absolute. Rather, they are seen as translatable possibilities. And because there's no ending to this translation process, they can only be reconstructed again and again, through open-ended practices. 


\section{5. “No solemn conclusions": how Landes left the field}

The addicted fieldworker does not really care for ease any more than does the competitive athlete. The lure of another culture can never be discounted, for it is the lure of the self, dressed otherwise.

Ruth Landes, A Woman Anthropologist in Brazil, 1970.

The 1930s and 1940s represent the decades of institutionalization of the social sciences in Brazil. This process took place in an insecure world, in which many scientists sought refugee from the Nazi-fascist ideologies. Europeans and North Americans also found many of these ideas in Brazil, since the country was under a dictatorship. ${ }^{19}$ Landes' own fieldwork was interrupted because the secret police, even without any formal accusation, wanted her out of Brazil. At the end of her ethnography, Landes states that there are no "solemn conclusions (...) from my observations in Bahia" (Landes, 1994 [1947], p. 248).

However, the consequences of the pioneering contributions of social scientists' such as Roger Bastide, Florestan Fernandes, Lévi-Strauss, Buell Quain, Charles Wagley are still very much a part of contemporary history in Brazil, when considering themes such as ethnographic authority, the Black Atlantic (Gilroy, 1993), comparative race relations, religious tolerance and diversity, democracy, sexual rights and erotic justice (Allen, 2012; Epprecht, 2013).

Ruth Landes' fieldwork experience can illustrate contemporary anthropologists' positions about different forms of oppression in Brazil today. As she states at the end of The City of Women:

I was sent to Bahia to learn how people behave when the Negroes are not oppressed. I found that they are oppressed by political and economic tyrannies, although not by racial ones. In that sense, the Negroes were free, and at liberty to cultivate their African heritage. But they were sick, undernourished, illiterate, and uninformed, just like the other poor people among them of different racial origins. It was their complete poverty that cut them off from modern thought and obliged them to make up their own secure universe (Landes, 1994 [1947]: 248).

In commenting on this passage, in the Introduction to the Brazilian edition of "The City of Women", Peter Fry (2002) evokes Landes' conclusions that there were no racial problems in Brazil, and asks a challenging question; Can we investigate the acceptance by transnational black movements that Brazil represented a "racial democracy"? For example, black leaders such as W.E.B. Du Bois and Booker T. Washington thought that Brazil could express positive aspects of the Black diasporic experience.

While I find this suggestion for future research fascinating and worth pursuing, I would also try to emphasise other passages in Landes' ethnography that reveal the hardship and exclusions that black people faced in Salvador. As we can see in the above quote, she highlighted that black people in Bahia suffered both hardship, illiteracy and a relative freedom to cultivate an "African heritage".

And if Landes (1986 [1970], pp. 122-123) is most remembered today for her empirical errors, as Matory (2005) has put it, we should not forget that she, reflecting on her training as an anthropologist and her fieldwork experience in Brazil, warned us that, in the field, anthropologists would constantly face the possibility of "erring" ${ }^{20}$. As she wrote:

19 Ruth Landes (1986 [1970], p. 120) commented on the Brazilian context of her fieldwork as follows: "I knew that Brazil in 1938 was governed by a severe dictatorship; that American pressure had barely forced Brazil's army to give up its Nazi-style ideology, called integralismo; that the so-called Axis powers were prominent in Brazilian commerce and that this was a land in the full prominence of patriarchal authority".

20 We could try to apply here the concept of equivocation (the same one that Ingold is "sick and tired of") as presented by Viveiros de Castro (2015). In building concepts and categories, anthropologists construct specific relationships with "natives", at the same time that they are situated at crossroads, at the intervals, of (at least) two different language games. In fabricating their tools of objectivation, anthropologists might find themselves in recursive situations that may lead them to an infinite synthesis. Viveiros de Castro assures us that "equivocations" are not mistakes because errors presuppose a stable language game, they carry the presumption that anthropologists know the conditions of truth in advance. We can now read Landes (1986 [1970]) reflecting on her fieldwork training and experience from a different perspective. 
Experience taught us (...) that in the field anything worked, even large mistakes, short of being killed.

Mistakes were, conceptually, evidences of cultures or culture bearers in conflict, and, in that perspective, were instructive. (...)

Field workers situated alone often feel private panic of being stranded in the oceanic vastness of a foreign people. One's concept of self disintegrates because the accustomed responses have disappeared; one seeks restoration through letters from home addressed to the remembered personality. There are loneliness, uprooting, fears and true and marked physical hardships, diseases, lack of diversions to relieve the tensions all of these nurture melancholics and spiritual fatigue.

We can now appreciate Landes' contributions with fresh eyes. Women anthropologists would not come to do fieldwork in Brazil until the 196os (Cole, 2003), the same decade Weston (1993) notes the effervescence in lesbian/gay studies in anthropology and the the gay liberation movement. A decade that also saw the so-called second-wave feminist movement (Henry, 2004).

Weston called the effervescence in lesbian/gay studies in the 196os the ethnocartographic movement. This was a movement interested in documenting the various ways societies around the world organise homosexualities and transgender experiences. Although Weston critically analyses the limitations of this early movement, she suggests that it was responsible for enlarging the contexts in which "transgendering and same-sex sexuality occur" (Weston, 1993, p. 345).

Thus, we can see that, along with Margaret Mead's and Ruth Benedict's early works on homosexuality and gender, Landes laid some foundations for scholarly works that would come decades later, fostering a shift in the anthropological canon. Furthermore, Landes was able to explore new forms of writing ethnography, building on the intersections between race, class, gender and sexuality.

\section{Acknowledgments}

The first version of this article was written in 2014 while I was studying in Sweden. I thank the Swedish Institute for awarding me a full scholarship to study at Lund University. I would also like to thank Ema Hrešanová, Jeffrey Hoff, and the three anonymous reviewers at Vibrant for their reading suggestions and comments.

Received on: November 29, 2017

Approved on: August 13, 2018

Translated by the author

Revision by Jeffrey Hoff 


\section{References}

ABU-LUGHOD, Lila. 2006. “Writing against Culture.” In: Feminist Anthropology: A Reader. Malden: John Wiley \& Sons. pp. 153-169.

ALLEN, Andrea Stevenson. 2012. "Brides' without Husbands: Lesbians in the Afro-Brazilian Religion Candomblé". Transforming Anthropology, 20(1): 17-31. . 2008. "Candomblé". In: Carole Elizabeth Boyce Davies (ed.), Encyclopedia of the African Diaspora: Origins, Experiences, and Culture [3 volumes]: Origins, Experiences, and Culture. Vol. 1. Santa Barbara: Abcclio. pp. 256-257.

ANDERSON, Jamie Lee. 2013. "Ruth Landes e Edison Carneiro: Matriarcado e Etnografia nos Candomblés da Bahia (1938-9)". Revista de História Da UEG, 2(1): 236-261. . 2012. "Edison Carneiro and Ruth Landes: Authority and Matriarchy in Candomblé Field Research, 1938-9". Berkeley Undergraduate Journal, 25(1): 117-145.

ASTUTI, Rita. 2017. “On keeping up the tension between fieldwork and ethnography”. HAU: Journal of Ethnographic Theory, 7(1): 9-14.

BECKER, Howard S. 1999. "The Chicago School, so-Called". Qualitative Sociology, 22(1): 3-12.

BEHAR, Ruth. 1993. "Introduction: Women Writing Culture: Another Telling of the Story of American Anthropology". Critique of Anthropology, 13(4): 307-325. .; GORDON, Deborah (ed.). 1995. Women Writing Culture. Berkeley: University of California Press. BOURDIEU, Pierre. 2000. Pascalian Meditations. Stanford: Stanford University Press.

BUTLER, Judith. 1990. Gender Trouble: Feminism and the Subversion of Identity. London: Routledge.

CARNEIRO, Edison. 2010. “Artur Ramos' Falsetto.” VIBRANT-Vibrant Virtual Brazilian Anthropology, 7(1): 20-24.

CLIFFORD, James. 1980. "Fieldwork, Reciprocity, and the Making of Ethnographic Texts: The Example of Maurice Leenhardt”. Man, 15(3): 518-532. . 1983. "On Ethnographic Authority”. Representations, 2: 118-146. . 2003. On the Edges of Anthropology: Interviews. Chicago: Prickly Paradigm Press. . 1997. Routes: Travel and Translation in the Late Twentieth Century. Cambridge: Harvard University Press.

CLIFFORD, James; MARCUS, George E. 1986. Writing Culture: The Poetics and Politics of Ethnography. Berkeley: University of California Press.

COLE, Sally. 1995a. “Women's Stories and Boasian Texts: The Ojibwa Ethnography of Ruth Landes and Maggie Wilson". Anthropologica, 37(1): 3-25. . 1995b. "Ruth Landes and the early ethnography of gender and race". In: R. Behar; D. Gordon (eds.), Women writing culture. Berkley: University of California Press. pp. 166-185. . 2002. "'Mrs. Landes Meet Mrs. Benedict': Culture Pattern and Individual Agency in the 1930s".

American Anthropologist, 104(2): 533-543. . 2003. Ruth Landes: A Life in Anthropology. Lincoln: University of Nebraska Press.

CORRÊA, Mariza. 200o. "O Mistério dos Orixás e das Bonecas: Raça e Gênero na Antropologia Brasileira". Etnográfica, 4(2): 233-265. . 2002. "Prefácio: esboços no espelho". In: A Cidade das Mulheres. Rio de Janeiro: Editora Universidade Federal do Rio de Janeiro. pp. 9-22.

DA COL, Giovanni. 2017. “Two or three things I know about Ethnographic Theory”. HAU: Journal of Ethnographic Theory, 7(1): 1-8.

EPPRECHT, Marc. 2013. Sexuality and Social Justice in Africa: Rethinking Homophobia and Forging Resistance. London: Zed Books.

FOUCAULT, Michel. 1998. The History of Sexuality. Vol. 1: The Will to Knowledge. London: Penguin Books. 
FRANKENBURG, Ruth. 1993. White women, race matters: The social construction of whiteness. London:

Routledge.

FRY, Peter. 2015. “Bacamarte em Pernambuco? René Ribeiro entre 6o Xangozeiros de Recife.” Bagoas-Estudos Gays: Gêneros e Sexualidades, 9(12): 138-150.

. 2002. "Apresentação" In: A Cidade das Mulheres. Rio de Janeiro: Editora Universidade Federal do Rio de Janeiro. pp. 23-30.

. 1986. "Male Homosexuality and Spirit Possession in Brazil." Journal of Homosexuality, 11(3-4): 137-153.

GEERTZ, Clifford. 1968. "Thinking as a Moral Act: Ethical Dimensions of Anthropological Fieldwork in the New States". The Antioch Review, 28(2): 139-158.

. 1973. "Thick description: Toward an Interpretative Theory of Culture." In: The Interpretation of

Cultures. New York: Basic Books. pp. 3-30.

GILROY, Paul. 1993. The Black Atlantic: Modernity and Double Consciousness. Cambridge: Harvard University Press.

GINZBURG, Carlo. 1989. “The Inquisitor as Anthropologist.” In: Clues, Myths, and the Historical Method.

Baltimore: John Hopkins University Press. pp. 156-164.

GORDON, Deborah. 1993. "Worlds of Consequences: Feminist Ethnography as Social Action". Critique of Anthropology, 13(4): 429-443.

HALL, Stuart; JEFFERSON, Tony (eds.). 2002. Resistance through rituals: Youth subcultures in post-war Britain. London: Routledge.

HANNERZ, Ulf. 2003. "Being There... and There... and There! Reflections on Multi-Site Ethnography". Ethnography, 4(2): 201-216.

HARAWAY, Donna. 1988. "Situated Knowledges: The Science Question in Feminism and the Privilege of Partial Perspective". Feminist Studies, 14(3): 575-599.

HEALEY, Mark. 1996. "Os Desencontros da Tradição em Cidade das Mulheres: Raça e Gênero na Etnografia de Ruth Landes”. Cadernos Pagu, 6/7: 153-199.

HENRY, Astrid. 2004. Not my mother's sister: Generational conflict and third-wave feminism. Bloomington: Indiana University Press.

HERSKOVITS, Melville J. 1948. "Review: The City of Women." American Anthropologist, 50(1): 123-125.

HOWELL, Signe. 2017. "Two or three things I love about ethnography.” HAU:Journal of Ethnographic Theory, 7(1): 15-20.

INGOLD, Tim. 2011. "Anthropology is not ethnography." In: Being alive: Essays on movement, knowledge and description. London: Routledge. pp. 229-243.

. 2014. "That's enough about ethnography!.” HAU: Journal of Ethnographic Theory, 4(1): 383-395. . 2017. "Anthropology contra ethnography." HAU:Journal of Ethnographic Theory, 7(1): 21-26.

KOLSHUS, Thorgeir. 2017. "The power of ethnography in the public sphere". HAU:Journal of Ethnographic Theory, 7(1): 61-69.

LANDES, Ruth. 1940. "Fetish Worship in Brazil". The Journal of American Folklore, 53(210): 261-70. . 1953. "Negro Slavery and Female Status". African Affairs, 52(206): 54-57. . 1970. The Prairie Potawatomi: Tradition and Ritual in the Twentieth Century. Madison: University of Wisconsin Press. . 1986. “A woman anthropologist in Brazil". In: Peggy Golde (ed.), Women in the field: Anthropological experiences. Berkley: University of California Press. pp. 119-139.

. 1994. The City of Women. Albuquerque: University of New Mexico Press.

. 2010. "A Cult Matriarchate and Male Homosexuality". VIBRANT-Vibrant Virtual Brazilian Anthropology, $7(1): 386-397$. 
LIVHOLTS, Mona. 2012. Emergent Writing Methodologies in Feminist Studies. London: Routledge.

MARCUS, George; FISCHER, Michael. 1986. Anthropology as Cultural Critique: An Experimental Moment in the Human Sciences. Chicago: University of Chicago Press.

MASSI, Fernanda P. 1991. Estrangeiros no Brasil: a missão francesa na Universidade de São Paulo. Master Thesis, State University of Campinas, UNICAMP - Campinas.

MATORY, J. Lorand. 2005. Black Atlantic Religion: Tradition, Transnationalism, and Matriarchy in the AfroBrazilian Candomblé. Princeton: Princeton University Press.

2008. "Feminismo, Nacionalismo e a Luta pelo Significado do Adé no Candomblé: ou, como Edison Carneiro e Ruth Landes inverteram o curso da história". Revista de Antropologia, 51(1): 107-121.

MCCLINTOCK, Anne. 1995. “Psychoanalysis, Race and Female Fetishism.” In: Imperial Leather: Race, Gender, and Sexuality in the Colonial Contest. London: Routledge. pp. 181-203.

MILLER, Daniel. 2017. "Anthropology is the discipline but the goal is ethnography”. HAU: Journal of Ethnographic Theory, 7(1): 27-31.

MOHANTY, Chandra Talpade. 2003. Feminism without Borders: Decolonizing Theory, Practicing Solidarity.

Durham: Duke University Press.

PACHECO DE OLIVEIRA, João. 1988. Nosso Governo: Os Ticunas e o Regime Tutelar. São Paulo: Marco Zero.

PEIRANO, Mariza G. S. 1998. "When anthropology is at home: the different contexts of a single discipline". Annual Review of Anthropology, 27(1): 105-128.

RAMOS, Artur. 2010. "Foreign Research on Brazilian Blacks". VIBRANT-Vibrant Virtual Brazilian Anthropology, $7(1): 11-19$.

SAHLINS, Marshall. 1993. "Goodbye to Tristes Tropes: Ethnography in the Context of Modern World History”. Journal of Modern History, 65(1): 1-25.

SAID, Edward. 1994. Culture and Imperialism. New York: Vintage.

SALZANO, Francisco M. 2009. “A Antropologia no Brasil: é a Interdisciplinaridade Possível?”. AmazônicaRevista de Antropologia, 1(1): 14-27.

SHAH, Alpa. 2017. "Ethnography? Participant observation, a potentially revolutionary praxis." HAU: Journal of Ethnographic Theory, 7(1): 45-59.

STRATHERN, Marilyn. 1987. "An awkward relationship: The case of feminism and anthropology”. Signs: Journal of Women in Culture and Society, 12(2): 276-292.

VISWESWARAN, Kamala. 1997 "Histories of Feminist Ethnography”. Annual Review of Anthropology, 26(1): 591-621.

VIVEIROS DE CASTRO, Eduardo Batalha. 2015. The relative native: Essays on Indigenous conceptual worlds. London: Hau Books.

WESTON, Kath. 1993. "Lesbian/gay studies in the house of anthropology". Annual Review of

Anthropology, 22(1): 339-367.

José Hildo de Oliveira Filho

CAPES scholarship holder, Process number 88881.171699/2018-01.

PhD Candidate, Charles University in Prague, CUNI, Czech Republic

https://orcid.org/oooo-0002-8774-1447

E-mail:79411295@fsv.cuni.cz 